\title{
TREATMENT OUTCOME OF DRY SOCKET FOLLOWING IMMEDIATE IMPLANT PLACEMENT USING PLATELET RICH FIBRIN: A PROSPECTIVE MULTI-CENTRE CLINICAL STUDY
}

\author{
Omar Hassan Soliman*
}

\begin{abstract}
Objectives: Dry socket is a common post-extraction complication. It is possible to occur following immediate implant placement. This study was designed to assess the efficacy of PRF for the management of established dry socket following immediate implant placement.

Materials and Methods: Twenty patients with established dry sockets following immediate implant placement were included. Patients were divided randomly, patients of group I were treated by socket curettage and irrigation, while in group II PRF was inserted in the space around the implant and filled the socket. Pain and granulation tissue formation score has been used to assess both groups.
\end{abstract}

Results: The pain score was 6 to 10 on the day zero, 3 to 6 on the day four and 1 to 3 on the day seven in group I, while in group II the pain score was 6 to 10 on the day zero, 0 to 3 on the day four and 0 to 1 on the day seven $(p 0.001)$. On group II the formations of granulation tissue appeared earlier than group I. Four implants failed, three implants in group I and one implant in group II.

Conclusion: This study suggests that the use of PRF for the management of dry socket following immediate implant placement relieves pain, accelerates the process of wound healing and increases implant success rate.

KEY WORD: Dry socket, Immediate implant placement, PRF.

\section{INTRODUCTION}

Immediate implant placement decrease the time of patient management. It has been become the treatment of choice especially for single implant case. Periapical infection at the site scheduled for immediate implant placement considered a potential risk factor to its success. An anaerobic pathogens arises from an infection may contaminate the implant during the healing process Vignolett $\boldsymbol{F}$ et.al. 2009.

\footnotetext{
* Lecturer of Oral Medicine, Periodontology and Oral Diagnosis. South Valley University
} 
A dry socket is a common post-extraction complications. The worldwide incidence of the dry socket is $4 \%$ of tooth extraction Aqsa $\mathbf{K}$ et.al 2020. The predisposing factors for dry socket after tooth extraction are trumatic extraction, infection, surgeon and patients factors. Caso A et. al. 2005. Other studies showed high incidence of dry socket in females Garcia AG et.al.2003, Bade oral hygiene and clot lysis Bloomer CR 2012.

Manifestations of the dry socket are throbbing pain, bad odour, trismus with or without lymphadenopathy. The dry socket affections are its typical appearance on the 2 nd or 3rd day postextraction, lasts for about 10 or 15 days and the patients complain from severe pain which is difficult to control even if a potent analgesic is used.

The main etiological factor behind the dry socket is clot lysis due to the presence of high level of fibrinolytic activity in the extraction socket, which results in bare bone and nerve endings exposure. The infectious process release kinins which responsible for pain. Bloomer CR 2012.

Management of dry socket was initially with antibacterial agents Noroozi A \& Philbert R 2009, lavage, anti-fibrinolytic agents, steroidal antiinflammatory agents and clot supportive agents Bloomer C 2012. Alternative intervention includes plasma rich growth factors and low laser level Kaya GS et.al 2011. Platelet-rich fibrin entraps circulating stem cells which differentiate into osteoblast phenotype, that promote osseous defects healing Choukroun J, et.al.2006. Rutkowski et al., in 2010 concluded that PRP promotes bone formation postextraction. Platelet-rich growth factor enhance soft and hard tissue Aqsa K et.al 2020.

The aim of the presented study was to investigate the efficacy of PRF for the treatment of dry socket following immediate implant placement compared with conventional methods.

\section{MATERIALS AND METHODS}

\section{Subject population}

The presented study was designed as a multicentre clinical prospective study. Three clinical centres were involved in this study, including Department of Oral Medicine, Periodontology and Oral Diagnosis, Faculty of Dentistry, South Valley University and two private dental clinics. All the centres were followed the same surgical and treatment protocol and all the operations done by the same surgeon. Recruitment of patients and performance of the surgeries took place between March 2019 and March 2020 according to inclusion and exclusion criteria. The included patients were who underwent immediate implant placement under local anaesthesia. After extraction and immediate implant placement patients were instructed to bite on sterile gauze for 60 minutes for homeostasis achievement. Clot had to present before dismissed the patients. Patients were instructed to return to the clinic for reexaminations if they suffered from postoperative pain. 20 patients with established dry socket following immediate implant placement were included. Diagnosis of the dry socket was based on: Major symptom (patients complained of throbbing pain for one or more days following immediate implant placement, hypersensitivity on gentle probing of the socket, bad odour or trismus) and sign of bare bone or blood clot loss. If the patients had a minimum of one sign and two symptoms diagnosed as dry socket.

\section{Inclusion criteria}

The age of all patients were between 18 and 60 years. Patients diagnosed with dry socket following immediate implant placement and suffered from postoperative pain. Patients had good oral hygiene. 


\section{Exclusion criteria}

Patients age under 18 years or above 60 years, pregnancy, medically compromised patients, complicated tooth extraction or damage to the socket walls during extractions.

\section{Study design}

The study included 20 patients with dry socket after extraction and immediate implant placement. Patients were divided randomly into two groups with 10 patients in each group. Patients were treated by curettage and saline irrigation under local anaesthesia in group I, while in group II PRF was inserted into the socket after curettage and irrigation with saline. Platelet rich fibrin was prepared as follows, 10 millilitres of the patient blood centrifuged at $3000 \mathrm{rpm}$ for 15 minutes. Surgical tweezer has been used to deliver PRF into the socket. Patients were followed up on the 4th and 7th day postoperative. Assessment parameters were pain and granulation tissue formation in the socket.

1. Pain was evaluated by as follows: No pain (score 0 ): No need for analgesic. Mild pain (scores 1 to 3): One tablet of $50 \mathrm{mg}$ Cataflam per day. Moderate pain (scores 4 to 6): Two tablets of 50 mg Cataflam per day. Severe pain (scores 7 to 10): More than two tablets of $50 \mathrm{mg}$ Cataflam per day. The time required for the complete pain relief was recorded.
2. Healing was measured by granulation tissue covered the socket: No healing (Nil), score 1 if $1 / 4$ of the socket covered by the granulation tissue, score 2 if $1 / 2$ of the socket covered by the granulation tissue, score 3 if $2 / 3$ of the socket covered by the granulation tissue, score 4 if $3 / 4$ of the socket covered by the granulation tissue. Time required for complete healing was recorded.

\section{RESULTS}

A total of 20 patients diagnosed with dray socket following immediate implant placement were included in the study from 561 implants placed immediately after tooth extraction under local anaesthesia at multi-centre clinic over a 12 months period. The pain score was 6 to 10 on the day zero (the presentation day), 3 to 6 on the day four and 1 to 3 on the day seven in group I, while in group II the pain score was 6 to 10 on the day zero, 0 to 3 on the day four and 0 to 1 on the day seven. Granulation tissue formation within the socket appeared clearly on the day 7 in both groups but group II showed much earlier granulation tissue by day 4 . Four implants were failed due to severe pain and inflammation, three implants in the group I and one implant in the group II. 
TABLE (1) Pain and granulation tissue score .

\begin{tabular}{|c|c|c|c|c|c|c|c|c|c|}
\hline \multirow{2}{*}{$\begin{array}{c}\text { Patient } \\
\text { No }\end{array}$} & \multirow{2}{*}{$\begin{array}{c}\text { Patient } \\
\text { age }\end{array}$} & \multirow{2}{*}{$\begin{array}{l}\text { Patient } \\
\text { gender }\end{array}$} & \multirow{2}{*}{$\begin{array}{c}\text { Treatment } \\
\text { groups }\end{array}$} & \multicolumn{2}{|c|}{ Day Zero } & \multicolumn{2}{|c|}{ Day Four } & \multicolumn{2}{|c|}{ Day Seven } \\
\hline & & & & Pain & GT & Pain & GT & Pain & GT \\
\hline 1 & 49 & Male & I & 10 & Nil & 6 & Nil & 1 & 3 \\
\hline 2 & 40 & Female & I & 8 & Nil & 5 & Nil & 2 & 1 \\
\hline 3 & 29 & Male & I & 9 & Nil & 6 & Nil & Failed & Failed \\
\hline 4 & 38 & Male & I & 6 & Nil & 2 & 1 & 1 & 3 \\
\hline 5 & 33 & Male & I & 8 & Nil & 3 & 1 & 0 & 4 \\
\hline 6 & 38 & Female & I & 7 & Nil & 3 & Nil & 0 & 4 \\
\hline 7 & 35 & Male & I & 9 & Nil & 6 & Nil & Failed & Failed \\
\hline 8 & 28 & Female & I & 10 & Nil & 6 & Nil & Failed & Failed \\
\hline 9 & 39 & Female & I & 9 & Nil & 5 & Nil & 3 & 2 \\
\hline 10 & 53 & Female & I & 9 & Nil & 5 & Nil & 3 & 2 \\
\hline 11 & 40 & Female & II & 8 & Nil & 2 & 1 & 0 & 4 \\
\hline 12 & 57 & Male & II & 9 & Nil & 0 & 3 & 0 & 4 \\
\hline 13 & 23 & Male & II & 8 & Nil & 1 & 2 & 1 & 4 \\
\hline 14 & 36 & Male & II & 9 & Nil & 2 & 2 & 1 & 3 \\
\hline 15 & 23 & Female & II & 10 & Nil & 4 & Nil & Failed & Failed \\
\hline 16 & 27 & Male & II & 10 & Nil & 3 & 1 & 0 & 4 \\
\hline 17 & 23 & Male & II & 9 & Nil & 2 & 2 & 0 & 4 \\
\hline 18 & 40 & Female & II & 8 & Nil & 2 & 1 & 1 & 3 \\
\hline 19 & 38 & Female & II & 9 & Nil & 0 & 3 & 0 & 4 \\
\hline 20 & 30 & Female & II & 7 & Nil & 0 & 3 & 0 & 4 \\
\hline
\end{tabular}



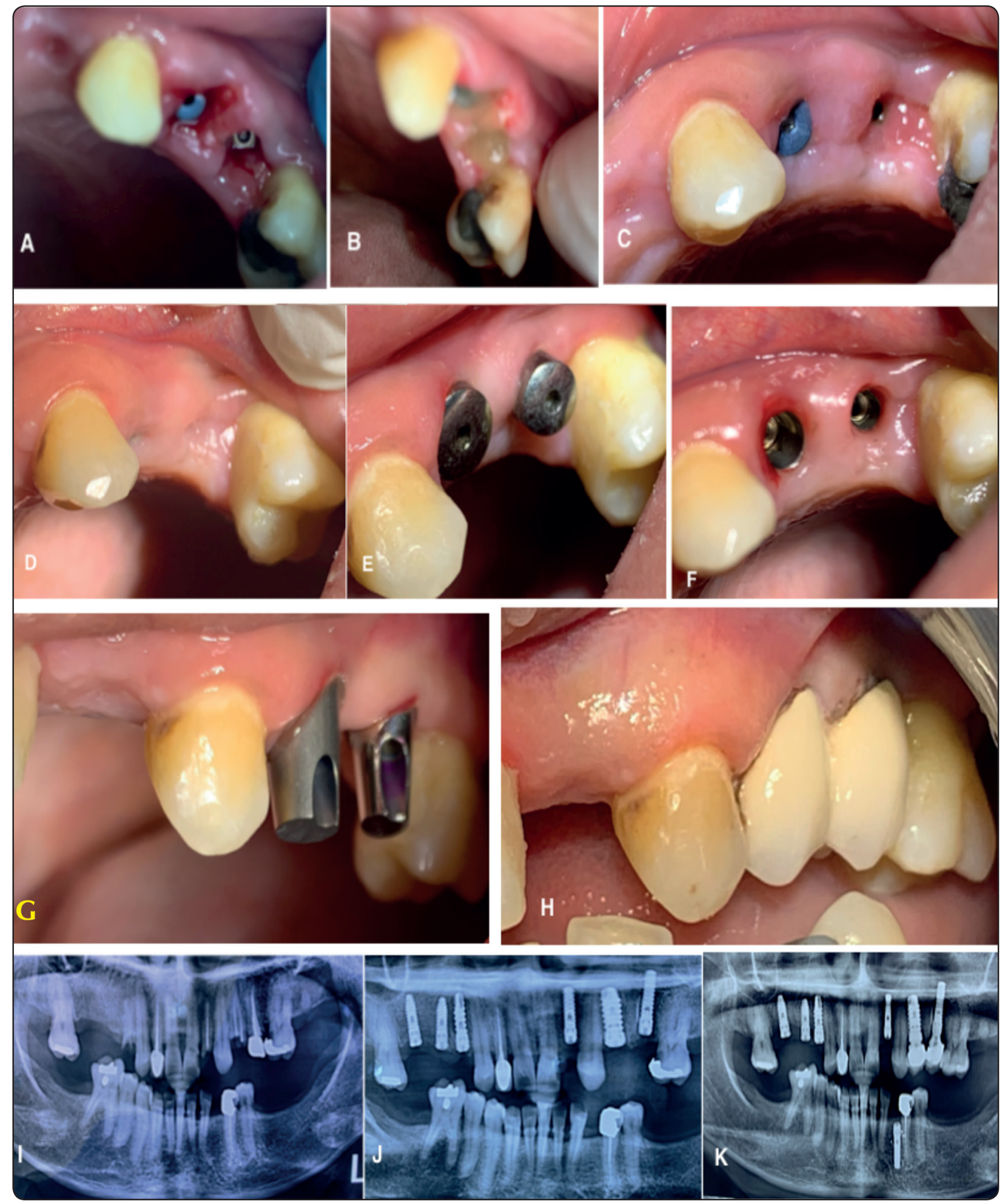

Fig. (1) Showing: Dry socket after immediate implant placement (A), PRF filled in the dry socket (B), Healing after 7 days (C), The ridge three months post-operation (D), Placement of the Healing abutment (E), Gingiva after removing the healing abutment $(F)$, Abutment connection $(G)$, Crowns cementation $(H)$ Preoperative panoramic x ray (I), Panoramic x ray after immediate implant placement $(\mathrm{K})$ and Panoramic $\mathrm{x}$ ray after crowns cementation $(\mathrm{J})$. 


\section{DISCUSSION}

Immediate implant placement involves inserting a fixture into a post-extractive alveolus. The modelling and remodelling process of immediate implant placement differ from the implant placed in the ridge Botticelli et al 2006. Marginal gap usually occurred in-between the socket wall and implant surface which immediately placed after extraction. If the blood clot allowed to heal, this gap does not disturb the osseointegration Botticelli et al. 2003. The dry socket is devoid of blood clot and bare-bone is present. Dry socket causes severe pain and impedes the normal healing process of the extraction sockets. Dry socket is a common post-extraction complication. The reported worldwide incidence of the dry socket is from 1 to $4 \%$ following routine tooth extraction Kamal A et.al. 2020. The results of this study showed that the incidence of the dry socket following immediate implant placement was 3.5\%, this consistent with the worldwide incidence of the dry socket after extraction of compromised tooth.

This a prospective multi-centre study was conducted to evaluate PRF efficacy in the treatment of dry socket after immediate implant placement. The study showed that all the twenty patients were suffered from severe pain on the presentation day, the range of pain score was from 6 to 10 . The blood clot in-between the socket and the implant surface was lost and this lead to fibrin degradation products which form kinins in the socket. Kinins and other inflammatory mediators cause intense pain Kamal A et.al. 2020. Patients in group I who were treated by conventional treatment, the range of pain score was from 4 to 6 on the day four and the score of granulation tissue formation was 1 . While patients who treated with PRF in group II showed much more improvement in pain score and more granulation tissue formation. PRF showed a higher potency of socket healing as it contains essential growth factors which speeds up the granulation tissue development. The results of this study showed that the conventional treatment alleviated the pain by granulation tissue formation but the recovery was slower than group II, this results was consistent with Kamal A et.al. 2020 which concluded that, placement of growth factors in the dray socket speed up the socket healing. In the conventional treatment of the dry socket, the reformation of blood clot was not effective as the first clot which formed immediately after extraction, while the formed blood clot after PRF treatment enhanced the socket healing. In group II the pain resolution was faster than group I. The Kinins released from dry socket antagonised by tissue growth factors which was present in PRF Singh et. al. 2014. PRF in this study showed faster and better healing which completed within seven days of treatment, this result was consistent with Kamal A et.al. 2020.

\section{CONCLUSION}

PRF contains growth factors which antagonise the kinins which are responsible for severe pain in dray socket. The use of PRF for the treatment of the dry socket following immediate implant placement decreases the pain, speeds up the socket healing and increases the success rate of immediate implant placement.

\section{REFERENCES}

- $\quad$ Anitua E, Orive G. Use of PRGF to accelerate bone and soft tissue regeneration in postextraction sites. Implant Dialogue 2003;36:3- 14 .

- Alexander RE. Dental extraction wound management: a case against medicating postextraction sockets. J Oral Maxillofac Surg 2000;58:538-51.

- Aldecoa EA, Ortiz IA. A mew approach to bone regeneration: plasma rich in growth factors. Vitoria: Puesta al Dia Publicaciones; 2001:172.

- $\quad$ Akimoto, K., Becker, W., Persson, R., Baker, D.A., Rohrer, M. D. \& O’Neal, R. B. (1999) Evaluation of titanium implants placed into simulated extraction sockets: a study in dogs. International Journal of Oral and Maxillofacial Implants 14, 351-360. 
- Aqsa Kamal, Basheer Salman,Noor Hayati Abdul Razak, Ali Al Qabbani: The Efficacy of Concentrated Growth Factor in the Healing of Alveolar Osteitis: A Clinical Study. International Journal of Dentistry Volume 2020, Article ID 9038629, 9 pages.

- Blum IR. Contemporary views on dry socket (alveolar osteitis): a clinical appraisal of standardization, aetiopathogenesis and management: a critical review. Int J Oral Maxillofac Surg 2002;31:309.

- Bloomer CR. Straws do not cause dry sockets when third molars are extracted. Tex Dent J 2012;129:25-32.

- Blum IR. Contemporary views on dry socket (alveolar osteitis): a clinical appraisal of standardization, aetiopathogenesis and management: a critical review. Int J Oral Maxillofac Surg 2002;31:309-17.

- Burgoyne CC, Giglio JA, Reese SE, Sima AP, Laskin DM. The efficacy of a topical anesthetic gel in the relief of pain associated with localized alveolar osteitis. J Oral Maxillofac Surg 2010;68:144-8.

- $\quad$ Botticelli, D., Persson, L. G., Lindhe, J. \& Berglundh, T. (2006) Bone tissue formation adjacent to implants placed in fresh extraction sockets: an experimental study in dogs. Clinical Oral Implants Research 17,351-358.

- Caso A, Hung LK, Beirne OR. Prevention of alveolar osteitis with chlorhexidine: a meta-analytic review. Oral Surg Oral Med Oral Pathol Oral Radiol Endod 2005;99:155-9.

- Cardoso CL, Rodrigues MT, Ferreira Júnior O, Garlet GP, de Car- valho PS. Clinical concepts of dry socket. J Oral Maxillofac Surg 2010;68:1922-32. Vezeau PJ. Dental extraction wound management: medicating postextraction sockets. J Oral Maxillofac Surg 2000;58:531-7.

- Choukroun J, Diss A, Simonpieri A, Girard M-O, Schoeffler C, Dohan SL, Dohan AJ, Mouhyi J, Dohan DM (2006) Platelet-rich fibrin (PRF): a second-generation platelet concentrate. Part V: Histologic evaluations of PRF effects on bone allograft maturation in sinus lift. Oral Surg Oral Med Oral Pathol Oral Radiol Endod 101:299-303.

- Daniel Torres Lagares, Ma Angeles Serrera Figallo, Manuel María Romero Ruíz, Pedro Infante Cossío, Manuel García Calderón, José Luis Gutiérrez Pérez:Update on dry socket: A review of the literature. Med Oral Patol Oral Cir Bucal 2005;10:77-85.

- Daly B, Sharif MO, Newton T, Jones K, Worthington HV. Local interventions for the management of alveo- lar osteitis (dry socket). Cochrane Database Syst Rev 2012;12:CD006968.

- $\quad$ Faizel S, Thomas S, Yuvaraj V, Prabhu S, Tripathi G. Comparision between neocone, alvogyl and zinc oxide eugenol packing for the treatment of dry socket: a double blind randomised control trial. J Maxillofac Oral Surg 2015;14:312-20.

- $\quad$ Fazakerley M, Field EA. Dry socket: a painful post-extraction complication (a review). Dent Update 1991;18:31-4.

- $\quad$ Fridrich KL, Olson RA. Alveolar osteitis following surgical removal of mandibular third molars. Anesth Prog 1990;37:32-41.

- Garcia AG, Grana PM, Sampedro FG, Diago MP, Rey JM. Does oral contraceptive use affect the incidence of complications after extraction of a mandibular third molar? $\mathrm{Br}$ Dent J 2003;194:453-5; discussion 445.

- Haraji A, Lassemi E, Motamedi MH, Alavi M, Adibnejad $\mathrm{S}$. Effect of plasma rich in growth factors on alveolar osteitis. Natl J Maxillofac Surg 2012;3:38-41.

- Halberstein RA, Abrahmsohn GM. Clinical management and control of alveolalgia (“dry socket”) with vitamin C. Am J Dent 2003;16:152-4.

- Haghighat A, Bahri Najafi R, Bazvand M, Badrian H, Khalighinejad N, Goroohi H. The effectiveness of GECB pastille in reducing complications of dry socket syndrome. Int J Dent 2012;2012: 587461.

- John Mamoun : Dry Socket Etiology, Diagnosis, and Clinical Treatment Techniques. J Korean Assoc Oral Maxillofac Surg 2018;44:52-58.

- Jovanović G, Urić N, Krunić N, Tijanić M, Stojanović S. Assess- ment of the effectiveness of low level laser in the treatment of alveolar osteitis. Vojnosanit Pregl 2011;68:506-10

- Kaya GŞ, Yapici G, Savaş Z, Güngörmüş M. Comparison of alvogyl, SaliCept patch, and low-level laser therapy in the management of alveolar osteitis. J Oral Maxillofac Surg 2011;69:1571-7.

- Kamal Aqsa, Basheer Salman, Noor Hayatie Abdul Razak: A Comparative Clinical Study between Concentrated Growth Factor and Low-Level Laser Therapy in the Management of Dry Socket. European Journal of Dentistry Vol. 14 No. 4/2020. 
- Kolokythas A, Olech E, Miloro M. Alveolar osteitis: a comprehensive review of concepts and controversies. Int J Dent 2010;2010:249073.

- Larsen PE. The effect of a chlorhexidine rinse on the incidence of alveolar osteitis following the surgical removal of impacted mandibular third molar. J Oral Maxillofacial Surg 1991;49:932-7.

- Martínez-Zapata MJ, Martí-Carvajal A, Solà I, Bolibar I, Angel Expósito J, Rodriguez L, et al. Efficacy and safety of the use of autologous plasma rich in platelets for tissue regeneration: a sys- tematic review. Transfusion 2009;49:44-56.

- Mozzati M, Martinasso G, Pol R, Polastri C, Cristiano A, Muzio G, et al. The impact of plasma rich in growth factors on clinical and biological factors involved in healing processes after third molar extraction. J Biomed Mater Res A 2010;95:741-6.

- Muhonen A, Ventä I, Ylipaavalniemi P. Factors predisposing to postoperative complications related to wisdom tooth surgery among university students. J Am Coll Health 1997;46:39-42.

- Noroozi AR, Philbert RF. Modern concepts in understanding and management of the "dry socket" syndrome: comprehensive review of the literature. Oral Surg Oral Med Oral Pathol Oral Radiol En- dod 2009;107:30-5.

- Reekie D, Downes P, Devlin CV, Nixon GM, Devlin H. The prevention of 'dry socket' with topical metronidazole in general dental practice. Br Dent J 2006;200:210-3; discussion 206; quiz 226.

- Rutkowski JL, Johnson DA, Radio NM, Fennell JW. Platelet rich plasma to facilitate wound healing following tooth extraction. J Oral Implantol 2010;36:11-23.

- Rani A, Mohanty S, Sharma P, Dabas J. Comparative evaluation of Er:Cr:YSGG, diode laser and alvogyl in the management of alveolar osteitis: a prospective randomized clinical study. J Maxillofac Oral Surg 2016;15:349-54.

- $\quad$ Pal US, Singh BP, Verma V. Comparative evaluation of zinc oxide eugenol versus gelatin sponge soaked in plasma rich in growth factor in the treatment of dry socket: an initial study. Contemp Clin Dent 2013;4:37-41.
- Peñarrocha M, Sanchos JM, Sáez U, Gay C, Bagán JV. Oral hygiene and postoperative pain after mandibular third molar surgery. Oral surg Oral Med Oral Pathol Radiol En$\operatorname{dod} 2001 ; 92: 260-4$.

- Plachokova AS, Nikolidakis D, Mulder J, Jansen JA, Creugers NH. Effect of platelet-rich plasma on bone regeneration in dentistry: a systematic review. Clin Oral Implants Res 2008;19:539-45.

- $\quad$ Singh V, Pal US, Singh R, Soni N. Honey a sweet approach to alveolar osteitis: a study. Natl J Maxillofac Surg 2014;5:31-4

- Sammartino G, Tia M, Marenzi G, di Lauro AE, D'Agostino E, Claudio PP. Use of autologous platelet-rich plasma (PRP) in periodontal defect treatment after extraction of impacted mandibular third molars. J Oral Maxillofac Surg 2005;63:766-70.

- $\quad$ Simon D, Manuel S, Geetha V, Naik BR. Potential for osseous regeneration of platelet-rich plasma--a comparative study in mandibular third molar sockets. Indian J Dent Res 2004;15:133-6.

- $\quad$ Song JY, Kweon H, Kwon KJ, Park YW, Kim SG. The bone regenerative effect of silk fibroin mixed with platelet-rich fibrin (PRF) in the calvaria defect of rabbit. J Korean Assoc Oral Maxillofac Surg 2010;36:250-4.

- $\quad$ Sharif MO, Dawoud BE, Tsichlaki A, Yates JM. Interventions for the prevention of dry socket: an evidence-based update. Br Dent J 2014;217:27-30.

- Taberner-Vallverdú M, Nazir M, Sánchez-Garcés MÁ, Gay-Escoda C. Efficacy of different methods used for dry socket management: a systematic review. Med Oral Patol Oral Cir Bucal 2015;20:e633- 9.

- Torres-Lagares D, Serrera-Figallo MA, Romero-Ruíz MM, Infante- Cossío P, García-Calderón M, GutiérrezPérez JL. Update on dry socket: a review of the literature. Med Oral Patol Oral Cir Bucal 2005;10:81-5; 77-81.

- Vignoletti F, et al. Early healing of implants placed into fresh extraction sockets: an experimental study in the beagle dog. II: ridge alterations. J Clin Periodontol. 2009; 36(8):688-97. 